\title{
The Struggle for Judicial Independence in Antebellum North Carolina: The Story of Two Judges
}

\author{
Walter F. Pratt, Jr.
}

The Supreme Court of North Carolina is an anomaly among state courts in the antebellum years. In a period dominated by democratic reforms of state government, the court did not merely survive unscathed it actually increased its independence. The remarkable success of this court is largely attributable to the personal reputations and political acumen of two of its judges, Thomas Ruffin and William Gaston. Without those two men it is likely that the Supreme Court would have been abolished in a wave of democratic reforms that peaked in North Carolina with the constitutional amendments of $1835 .^{\prime}$

Walter F. Pratt, Jr. is Associate Professor of Law, Duke University.

An earlier version of this article was presented at the 1982 meeting of the American Society for Legal History. Judge Willis Whichard, of the North Carolina Court of Appeals, Professor Blackwell P. Robinson, of the University of North Carolina at Greensboro, and Professor John Orth, of the University of North Carolina Law School, kindly read a draft of the manuscript and offered suggestions for which I am grateful. I benefitted from a year at J. Reuben Clark Law School, Brigham Young University, during which I completed work on this article. I am indebted to the helpful and efficient staffs at the North Carolina State Archives, the North Carolina Collection and the Southern Historical Collection, both at the University of North Carolina in Chapel Hill, and the Rare Book Room and Archives Collection at the Perkins Library of Duke University. All quotations from those collections are used with permission.

Editor's note: To simplify certain recurring references the following abbreviations will be used:

State Archives-North Carolina State Archives, Raleigh, North Carolina.

N.C. Coll.-North Carolina Collection, University of North Carolina at Chapel Hill, Chapel Hill, North Carolina.

SHC-Southern Historical Collection, University of North Carolina at Chapel Hill, Chapel Hill, North Carolina.

Duke RBR--Rare Book Room, Perkins Library, Duke University, Durham, North Carolina.

Raleigh Register-Raleigh Register and North-Carolina State Gazette.

New Bern Spectator-New Bern Spectator and Literary Gazette

The Star (Raleigh)-The Star and North Carolina State Gazette.

I. Joseph Gales, a Raleigh printer, published the proceedings of the 1835 constitutional convention in 1836 under the title Proceedings and Debates of the Convention of 
During the first half of the nineteenth century most state judiciaries were the focus of a debate over "the position and powers of the judicial department' ${ }^{2}$ Efforts to secure the judiciary as a separate, independent branch of government were countered by increasing demands to make state government more democratic. Those who favored an independent judiciary found themselves opposed by democrats who thought that all governmental officials should be elected by the people for limited terms. ${ }^{3}$ Democrats preferred a system of courts patterned after the Court of King's Bench which had no superior appellate court. Under that system the judges of trial courts rode circuit (thereby renewing contacts with the people) and met periodically to review their own decisions. ${ }^{4}$ Opposed to that model was a judiciary he:aded by a supreme court with only appellate functions and whose judges were free of circuit and other responsibilities. The advocates of a separate supreme court saw it, along with tenure during good behavior, as the only way to secure the prestige and independence necessary to enable the judiciary to check the democracy of the legislature. ${ }^{5}$ The democrats perceived the independent model as fostering an elite group of judges., distanced in fact and thought from the people.

Beginning with Georgia in 1812, the judiciaries of a number of states succumbed as the floodgates of democracy opened onto the courts. ${ }^{6}$ The immediate causes of change were as varied as the states; but the underlying theme of democratic reform was common to all. The perennial problem of relief for debtors, for example, provoked retaliatory action against the courts of at least two states. In 1815 the Georgia legislature censured the superior court judges for declaring unconstitutional a law suspending the payment of debts. ${ }^{7}$ The judges had issued the collective declaration in their appellate

North-Carolina, Called to Amend the Constitution of the State. For an account of the convention see Robert D.W. Connor, 'The Convention of 1835', North Carolina Booklet viii (1908) 89-110; Harold J. Counihan, 'The North Carolina Constitutional Convention of 1835: A Study in Jacksonian Democracy', North Carolina Historical Review xlvi (1969) 335-64.

2. Fletcher M. Green, Constitutional Development in the South Atlantic States, 177(i-1860 (Chapel Hill, 1930) 301; see also Richard E. Ellis, The Jeffersonian Crisis: Courts and Politics in the Young Republic (New York, 1971) 7.

3. See Lawrence M. Friedman, A History of American Law (New York, 1973) 122-24; Fletcher M. Green, Constitutional Development, supra note 2; Gordon S. Wood, The Creation of the American Republic, 1776-1787 (Chapel Hill, 1969).

4. J. Willard Hurst, The Growth of American Law: The Law Makers (Boston, 1950) 101.

5. Cf. Erwin C. Surrency, 'The Development of the Appellate Function: The Pennsylvania Experience', American Journal of Legal History 20 (1976) 173-91.

6. See William S. Carpenter, Judicial Tenure in the United States (New Haven, 1918) 168-84; Lawrence M. Friedman, History, supra note 3 at 111; Evan Haynes, The Selection and Tenure of Judges (Newark, 1944) 80-135; J. Willard Hurst, Growth of American Law, supra note 4 at 101-02.

7. Len G. Cleveland, 'The Establishment of the Georgia Supreme Court', 9 Georgia State Bar Journal 417, $417-19$ (1973); see also Bond Almand, 'The Supreme Court of Georgia: An Account of Its Delayed Birth', 6 Georgia State Bar Journal 95, 98 (1943). 
capacity while gathered as a conference court. A decade later similar events led to an unsuccessful effort to remove the judges of Alabama's highest court for failing to provide relief for debtors. ${ }^{8}$ The process of democratic reform continued through the antebellum years, as evidenced by events in two other states that amended their constitutions contemporaneously with North Carolina's amendments of 1835. The most extreme of these two was in South Carolina, where the legislature abolished the supreme court in 1835 because the court had dared to invalidate a law considered vital to the state's stance on nullification. ${ }^{9}$ Two years later, debate on the judiciary dominated the proceedings in the Pennsylvania constitutional convention of $1837 .^{10}$ The convention proposed replacing tenure during good behavior with fifteen-year terms for judges. ${ }^{\text {II }}$

In North Carolina the movement for reform achieved two important successes in the 1835 convention: a more equal apportionment between east and west of seats in the legislature and the popular election of the governor. ${ }^{12}$ The convention did not, however, devote significant discussion to the courts, which is surprising in light of the fact that the preceding two decades had seen repeated attempts to revamp the courts. Those earlier efforts had prompted a warning that unless the electors carefully selected delegates for a proposed constitutional convention, 'they may expect to see the independence of the Judiciary prostrated at the shrine of Legislative caprice and ambition'. ${ }^{13}$ But those fears proved to be unfounded. The convention suggested only three amendments concerning the judiciary, each of which actually increased the independence of the judiciary. The most substantial increase in protection came from the declaration that the judges' salaries 'shall not be diminished during their continuance in office'. (The existing constitution, dating from 1776, contained no such protection.) The two other amendments clarified the constitution by specifying two methods

8. William H. Brantly, Jr., 'Law and Courts in Pioneer Alabama', 6 Alabama Lawyer 390, 395-98 (1945); Lucien D. Gardner, 'The Circuit Judges of Alabama', 1 Alabama Lawyer 280, 288-89 (1940).

9. Donald Senese, 'Building the Pyramid: The Growth and Development of the State Court System in Antebellum South Carolina, 1800-1860', 24 South Carolina Law Review 357, 367-69 (1972). A similar extreme reaction had occurred in 1823 in Kentucky, where the state legislature abolished the court of appeals and created a rival court in retaliation for the judges' striking down a debtor relief law. See Lawrence M. Friedman, History, supra note 3 at 115 .

10. J. Paul Selsam, 'A History of Judicial Tenure in Pennsylvania', 38 Dickinson Law Review 168, 176 (1934).

11. See ibid. at 176-79.

12. Fletcher M. Green, Constitutional Development, supra note 2 at 231-32. On sectionalism see Ora Blackmun, Western North Carolina: Its Mountains and Its People to 1880 (Boone, N.C., 1977) 130-33.

13. N.C. Coll., Broadsides, Charles Phelps, To the Freemen of Wilkes County, July 2, 1824. 
for removing judges from office: (1) impeachment 'for willfully violating any Article of the Constitution, mal-administration or corruption'; and (2) removal 'for mental or physical inability, upon a concurrent resolution of two-thirds of both branches of the General Assembly'. ${ }^{14}$ Both provisions appear fraught with ambiguities that could be of use to political opponents of the court. The effect of the two amendments, however, was to provide additional protection for the courts by making it clear that only the legislature could remove judges. The 1776 constitution, by contrast, allowed for indictment by a grand jury. ${ }^{15}$ Both amendments also provided protection through the substantial requirement of a two-thirds vote in each house. The 1776 constitution contained no such specification.

Moreover, both amendments afforded the court considerably more protection than a democratic amendment popular as early as 1819 . That earlier proposal would have allowed removal of judges 'for inability to perform their duty, or any other reasonable cause, on the address of both houses of the General Assembly for that purpose'. ${ }^{16}$ The earlier proposal also provided that judicial salaries could neither be increased nor decreased during a judge's tenure. The sponsor of the earlier amendment denied that he was opposed to the judiciary. He thought only that it was 'inconsistent with the principles of free Government, that there should be any branch of it perpetually excluded from the control of the people'. ${ }^{17}$ His full-blown democratic position included the belief that if the workload increased or the currency depreciated in value judges should resign and go before the legislature to seek an increase in salary. Then, if they were "worthy and capable men, they [would] be re-elected' ${ }^{18}$ Similar arguments gained strength through the 1820 s and the early 1830s. Yet by the time of the 1835 convention the court had secured itself against the onslaught of democratic reformers. To understand how the court could be so successful requires an understanding of the history of the court, with particular attention to Ruffin and Gaston ${ }^{19}$ and to their singular public response in an 1834 decision, Hoke v. Henderson. ${ }^{20}$

14. See Proceedings, supra note 1 at $422-23$.

15. North Carolina Constitution of $1776, \$ 23$.

16. Senate Journal, Dec. 2, 1819, 41, quoted in Raleigh Register, Nov. 26, 1819, p. 2, col. 5.

17. Raleigh Register, Dec. 1, 1819, p. 1, col. 3.

18. Ibid. at col. 4.

19. The third member of the court was the considerably less distinguished Joseph J. Ditniel. Ruffin disliked him, see SHC, William Gaston Papers, Ruffin to Gaston, Aug. 21, 1833. And Gaston had despaired when he learned of Daniel's appointment to the court, see ibid., Gaston to Hannah Manly, Dec. 31, 1832. See also Robert W. Winston, 'A Century of Law in North Carolina', 176 N.C. 763, 789 (1919) (Daniel described as being 'well-furnished').

20. 15 N.C. 1 (1834). Hoke was reversed in Mial v. Ellington, 134 N.C. 131 (1903). 
A.

North Carolina's first constitution contained only two provisions concerning the establishment of the judiciary. ${ }^{21}$ One directed that 'the General Assembly shall by joint ballot of both houses appoint judges of the Supreme Courts of Law and Equity, [and] Judges of Admiralty . . . who shall be commissioned by the Governor, and hold their offices during good behaviour' ${ }^{22}$ The other provision declared simply that judges should receive 'adequate salaries'. ${ }^{23}$ The legislature was apparently left free to decide whether there should be a hierarchy of courts, since the constitution mandated only one level. Furthermore, if the legislature decided to establish other courts, the constitution offered no instructions about tenure or jurisdiction. Even the judges' salaries were left for later determination and possible modification, with the use of 'adequate' rather than an explicit prohibition on reduction of the salaries. In short, the constitution left the legislature wide, though ill-defined, powers to fashion a judicial system. ${ }^{24}$

That the legislature did not feel constrained by the constitution is evident from the first statute creating courts for the newly independent state. Not one of the courts was 'supreme', either in name or in fact. In name, the first courts were 'superior courts', trial courts with jurisdiction throughout a circuit of counties. At first the legislature divided the state into six circuits with a single superior court sitting only in the major town within each circuit. ${ }^{25}$ By the early years of the nineteenth century, however, the growth of population had overwhelmed that system. In 1806 the legislature restructured the court system, directing that a judge of the superior court sit in each county according to a schedule established by the legislature. ${ }^{26}$

21. This was common in many state constitutions. See Fletcher M. Green, Constitutional Development, supra note 2 at 91-95. For discussions of the North Carolina Constitution see Robert D.W. Connor, 'Ante-Bellum Builders of North Carolina', North Carolina State Normal \& Industrial College Historical Publications iii (1914) 3, 22-25; Frank Nash, 'The North Carolina Constitution of 1776 and its Makers', James Sprunt Historical Publications xi, no. 2 (1912) 7-23.

22. North Carolina Constitution of $1776, \$ 13$. The uncertainty inherent in that provision is emphasized by subsequent proposals for amendment which would have added 'and superior' to make the phrase read: 'the General Assembly shall . . . appoint Judges of the Supreme and Superior Courts of law and Equity'. Raleigh Register, Nov. 18, 1823, p. 2, col. 1 .

23. North Carolina Constitution of $1776, \S 21$.

24. See Fletcher M. Green, Constitutional Development, supra note 2 at 91 (court system left to statutory enactment).

25. Act of 1777 , ch. $2, \S 2,1821$ N.C. Laws 282,281 , ch. $115, \S 2$. The legislature added a seventh circuit in 1787 . Act of 1787 , ch. 32, 1821 N.C. Laws 582 , ch. 281.

26. Act of 1806 , ch. 2, 1821 N.C. Laws 1050 , ch. 693. 
In fact, since no court was 'supreme', the superior court judges were co-equals. Before 1799 there was not even a formal structure to resolve disagreements among the superior courts. In that year the legislature directed the superior court judges to meet together to settle disputed issues of law and equity that arose on the circuits. ${ }^{27}$ For the first two years, however, these joint meetings were not acknowledged as a court; they even lacked a name. Then in 1801 the legislature took the first step toward creating a separate supreme court when it gave the name of 'conference court' to a joint meeting of the superior court judges. ${ }^{28}$ Four years later, in 1805 , the legislature renamed the court the supreme court of North Carolina' though the composition remained the same. ${ }^{29}$ In effect, the superior court judges continued to sit en banc to review their own decisions.

Not until 1818 did the legislature establish a separate Supreme Court of North Carolina, under the provisions of a bill introduced by William Gaston. ${ }^{30}$ The legislature continued to act as though the language of the constitution controlled little about the judiciary. Indeed, the governor had said as much in his message to the legislature at the beginning of the session: 'for wise purposes, no doubt, the framers of our constitution have granted to you the power of regulating ... this coordinate department of our government ' ${ }^{31}$ The governor did, however, think that the constitution required that the judges serve during good behavior ${ }^{32}$ But the legislature was not prepared to concede that point. Instead, it provided in the statute that three judges would be appointed by joint ballot of the two houses of the General Assembly and would 'hold office during good behaviour'. Those provisions would have been superfluous had there been agreement that the constitution controlled the legislature.

27. Act of 1799,1821 N.C. Laws 887 , ch. 520.

28. Act of 1801,1821 N.C. Laws 941 , ch. 576.

29. Act of 1805 , ch. 1, 1821 N.C. Laws 1039 , ch. 674. See generally William K. Boyd, History of North Carolina: The Federal Period, I783-1860, 2 vols. (Chicago, 1919) ii, 66-70; Guion G. Johnson, Ante-Bellum North Carolina (Chapel Hill, 1937) 613-43.

30. Act of 1818, ch. 1, 1821 N.C. Laws 1433, ch. 962 . For the text of the committee report recommending the supreme court see Raleigh Register, Dec. 4, 1818, p. 1, col. 1. See also N.C. Coll., Broadsides, A Letter from a Member of the General Assembly to One of his Constituents Respecting the Change in the Judiciary System, together with the Substance of Mr. Mebane's Speech on the Same Subject, 1818. The bill passed each house with a comfortable, but not overwhelming majority. See Raleigh Register, Dec. 11 , 1818, p. 2, col. 5 (71-53 vote in House of Commons); ibid., Dec. 18, 1818, p. 2, col. 3 (34-24 vote in Senate). A supplemental act continued the practice of th: old Conference Court by authorizing the judges themselves to select one of their number as chief justice. Act of 1818, ch. 2, 1821 N.C. Laws 1435, ch. 963.

31. Raleigh Register, Nov. 20, 1818, p. 2 col. 2; Raleigh Star, Nov. 20, 1818, p. 1, col. 4.

32. Ibid. (Both newspapers printed the governor's address.) 
B.

In the absence of substantial constitutional restraints on the legislature, the supreme court quickly became a target of attacks by democratic reformers. From the creation of the court the reformers objected to the expense of a court so removed from the people. ${ }^{33}$ The annual salary of $\$ 2500$ for each member of the court was higher than that for any other state official. The governor, for example, received only $\$ 2000 .{ }^{34}$ The president of the state bank earned $\$ 2500$ and was allowed to practice law in Raleigh. ${ }^{35}$ Furthermore, the total of $\$ 7500$ for judicial salaries was thought to be too extravagant for a state that never spent more than a quarter of a million dollars in any one year between 1818 and $1835 .{ }^{36}$

For many, though, the high salaries were only symptomatic of a general unresponsiveness of governmental institutions to the people, especially to the growing population of the western part of the state. The entire judiciary was thought to be flawed. At its lowest level the same elite who controlled appointments to county administrative offices also appointed judicial offi-

33. Raleigh Register, Dec. 11, 1818, p. 2, col. 3 (debate on motion to recommit bill to permit discussion of salary); ibid., Dec. 18, 1818, p. 2, col. 3. See also The Star (Raleigh), Jan. 1, 1819, p. 1, col. 1 (report of debate on salary). The next year the Senate passed, and the House joined, a resolution calling for an inquiry into whether the salaries were 'more than adequate to [the judges'] services'. Senate Journal, Nov. 27, 1819,28 ; ibid., Nov. $29,1819,31$. A bill to reduce the salaries failed by a vote of 34-26, with eastern delegates voting 23-13 against the bill and western delegates voting 13-11 in favor. See ibid., Dec. 23, 1819, 98. The bill had already passed the House. House Journal, Dec. 22, 1819, 92. The next year a majority of delegates from both east and west voted against reducing salaries. See Senate Journal, Dec. 4, 1820, 26.

34. Act of 1817 , ch. 25,1821 N.C. Laws 1415 , ch. 956 (increasing salary by $\$ 400$ ). See also Act of 1793, 1821 N.C. Laws 730, ch. 403 (list of salaries 'corrected in 1820'; Governor's salary listed as $\$ 2000$ ). But see Walter Clark, 'History of the Supreme Court of North Carolina', 177 N.C. 615, 620 (1919) (erroneously reports that the governor's salary was $\$ 1900$ ).

35. See Joseph G. de R. Hamilton, ed., The Papers of Thomas Ruffin, 2 vols. (Raleigh, N.C., 1918) i, 465 n.7. In a letter to David Swain, Ruffin reported that his salary plus his legal fees yielded him $\$ 4000$ annually. N.C. Coll., Epistolary Letters of David Swain, vol. 3, Ruffin to Swain, Oct. 15, 1829 (a typescript is in the SHC). The act which created the bank authorized the stockholders to set the compensation for the president. Act of 1810 , ch. $5, \$ 9,1821$ N.C. Laws 1171, 1176, ch. 788, $\$ 9$.

36. Robert D.W. Connor, North Carolina: Rebuilding an Ancient Commonwealth, 15841925, 2 vols. (Chicago, 1929) i, 466 (annual state expenditures ranged between $\$ 81,000$ and $\$ 224,000$ ). As indicated in note 33 supra, some legislators complained about the salary from the start. Other efforts to reduce the salary came later. See, e.g., Western Carolinian (Salisbury), Jan. 18, 1825, p. 3, col. 3 (bill to reduce salaries); Greensborough Patriot, Dec. 5, 1829, p. 2, col. 3 (bill to limit salaries to not more than $\$ 2,000$ ); ibid., Jan. 12,1831 , p. 2 , col. 1 (bill to reduce salaries to $\$ 2,000$ ). The salary remained fixed at $\$ 2,500$ at least through 1889 , no doubt in part the result of complaints that the salary was too high. See Kemp P. Battle, 'An Address on the History of the Supreme Court', 1 N.C. 834, 858 (1889; rev. ed. 1937). 
cials such as justices of the peace, sheriffs, and court clerks. ${ }^{37}$ The middle level of the judicial system, the superior courts, was as maldistributed (taking population as the guide) as were seats in the state's legislature.

The judicial circuits also reflected the imbalance of political power. The older, eastern circuits comprised smaller geographical areas as well as smaller counties. The first circuit, for example, lay around the Albermarle Sound, consisting of ten counties with a total land area of less than 4500 square miles. ${ }^{38}$ The population of that circuit increased by one-third from 54,000 in 1790 to 72,000 in 1840 . The newer, western circuits contained larger counties and more rapidly growing populations. The westernmost circuit, the sixth, covered almost 15,000 square miles with a population that nearly trebled in the same fifty-year period, growing from 57,000 in 1790 to almost 165,000 in 1840 . When combined with the relatively greater ease of transportation in the east, the result was that both judges and litigants could travel more readily to court in the east than in the west. As a member of the 'Mountain Bar' would later recall, in the antebellum years 'there was not an inch of railway iron or a navigable stream from Salisbury to Chattanooga. With few exceptions, mail facilities were limited to one delivery per week, carried on horseback. ${ }^{39} \mathrm{~A}$ legislator from the far western counties of Burke and Yancey painted an even grimmer picture of the problems in a broadside to his constituents which explained the need for a new circuit in the west: '[O]wing to the great length of time which the suits are kept in courts, it generally breaks up one party or the other with the accumulation of the cost'. He went on to note that the delays 'too often incited men to take the law into their own hands, and which too often results in [encounters] of a serious nature, and even in death itself ${ }^{40}$

37. Ora Blackmun, Western North Carolina, supra note 12, at 196-205, 261-62, 307; Paul W. Wager, County Government and Administration in North Carolina (Chapel Hill, 1928) 16-18; Max R. Williams, 'The Foundations of the Whig Party in North Carolina: A Synthesis and a Modest Proposal', North Carolina Historical Review xlvii (1970) 115, 115; Mabel Cuthrell, 'The County Court System of North Carolina, 1776-1835, With Special Reference to Rowan County', (unpublished M.A. thesis, Duke University, 1942) 58-59; see also discussion at 140 , with accompanying note 58 . 'These disputes resonated with many of the same themes that had characterized the Regulator movement over fifty years earlier. For examples of recent scholarship on the Regulators see James P. Whittenburg, 'Planters, Merchants, and Lawyers: Social Change and the Origins of the North Carolina Regulation', William and Mary Quarterly (3d ser.) xxxiv (1977) 215-238; Marvin L.M. Kay, 'The Institutional Background of the Regulation in Colonial North Carolina' (unpublished Ph.D. dissertation, University of Minnesota 1962).

38. The areas were computed from the statistics in William S. Powell, The North Carolina Gazetteer (Chapel Hill, 1968). The population statistics are collected in Jolin L. Cheney, Jr., ed., North Carolina Government, 1585-1979 (Raleigh, N.C., 1931).

39. State Archives, Allen T. \& Theodore F. Davidson Papers, 'Reminiscences and Traditions of North Carolina', address by Theodore F. Davidson to the Pen and Plate Club of Asheville, North Carolina, Nov. 1928.

40. State Archives, D.S. Reid Papers, T. Baker, To the Freemen of the Counties of Burke and Yancy, Jan. 21, 1837. 
The complaints were not restricted to the far western counties. The central counties, which voted with the west, had the same problems. Thus, as a member of the House of Commons from one of those counties complained: 'Our citizens have necessarily to travel too far to Court, and that over rapid water courses and rugged mountains-some of them to the distance of seventy-five to a hundred miles'. ${ }^{41}$ The distances provoked another legislator to emotive language when he wrote to his constituents at the end of the 1831-32 legislative session to express his support for a constitutional convention. Among his complaints was the unwillingness of the east to respond to the problems of the west by creating a new county in an area

where it is not uncommon for people to be compelled to go seventy five or eighty miles to court to transact even their smallest public business; and it not unfrequently happens that this distance is traveled on foot, and sometimes by a poor widowed woman, with her infant orphan in her arms, over frozen rivers, rocky hills and snow capped mountains, to take out letters of administration on a very small estate left by her deceased husband. ${ }^{42}$

In the absence of statistics on the workload of the courts, it is impossible to assess the accuracy of the perception that the western courts were more heavily burdened than those in the east. The persistency of the efforts to provide a remedy does, however, suggest that the complaint of court congestion was real, especially in equity courts. ${ }^{43}$ This congestion was aggravated by a statutory requirement that equity cases be heard only after jury trials were completed. ${ }^{44}$

Regardless of their origins, efforts to relieve the problems facing litigants came to focus on the supreme court, which already was the target of democratic attack. The malleability of the judiciary in these early years of the nineteenth century is evident from the legislature's effort to relieve the

41. Duke RBR., Pamphlets, Debate on the Convention Question in the House of Commons, Jan. 14, 1832, 32 (pamphlet published by Joseph Gales, Raleigh, N.C., 1832). Cf. Western Carolinian (Salisbury), Dec. 26, 1826, p. 2, col. 4 (editorial complaining of delays in courts of 'many of the large counties of this state').

42. N.C. Coll., Broadsides, J. Allison, To the Freemen of Orange County, Feb. 12, 1832.

43. For examples of these efforts see Raleigh Register, Nov. 24, 1820, p. 3, col. 1 (Governor's message to legislature); ibid., Dec. 9, 1823, p. 3, col. 2 (debate on proposals to, among others, allow the governor to call extra courts in counties with unusual congestion); ibid., Dec. 12,1823, p. 2 , col. 1 .

44. Act of 1777 , ch. $2, \S 34,1821$ N.C. Laws 297 , ch. $115, \S 34$ ('All jury causes shall be first tried'.) Cf. The Star (Raleigh), Oct. 23, 1818, at p. 3, col. 1 (letter from 'A Western Farmer of North Carolina' complaining that the combination of courts of law and equity was one case of delay); ibid., Nov. 13, 1818, p. 3, col. 1 (similar complaint in another letter); The Patriot (Greensborough), Feb. 24, 1827, p. 3, col. 1 (Guilford's legislative delegation reports on failure of bill to create equity courts; remarks on need for relief but west split over best means). A 1792 statute made it illegal for a court to hear other than equity cases during the last three days of its term. Act of 1792, ch. 8 . The statute is not included in the 1821 compilation of laws in force. See 1821 N.C. Laws 686-87. 
congestion in equity cases through the same statute that established the separate supreme court. The statute authorized any superior court sitting as a court of equity to remove a case to the supreme court 'on sufficient cause shown by affidavit rendering such removal necessary for the purposes of justice'. ${ }^{45}$ The hope behind that provision is apparent from the report of a senate committee in the following legislative session. The report announced that with the supreme court the state was at last provided with a court 'ready to receive those weighty and numerous equity suits, which have for so many years slept [unheeded] on the dockets of the courts in the west' ${ }^{46}$

But that statute provided little, if any, relief, since travel to Raleigh was no easier than travel to a county seat. Local counsel were unwilling to make the trip for fear of losing fees which they might have earned had they not traveled. Litigators from the west therefore often chose to hire special counsel in Raleigh to argue before the supreme court, undoubtedly at a higher cost. ${ }^{47}$ That unpalatable choice only added support to the familiar democratic attack on a distant court that knew little of the needs of the people ${ }^{48}$ The predictable companion to that complaint was a proposil to have the judges of the supreme court sit in equity courts throughout the state during the months when they were not required to hold court in Raleigh. ${ }^{49}$

No blend of democratic argument with remedies for relieving congestion could allay the fears of many politicians of the Whig or old Federalist school that each reform suggestion was motivated by a desire to abolish the supreme court altogether. ${ }^{50}$ William Gaston, a former Federalist who llater became a Whig, expressed those concerns in a letter written to Bartlett Yancey in 1821. Gaston feared that the next session of the legislature held much danger for the supreme court, then only three years old. The enemies of the court, he predicted, planned 'to make a mob [mock?] court of it by getting the [Circuit] Judges on it and thus destroying its most valuable features, its perfect separation from the tribunals whose decisions it revises'.

45. Act of 1818 , ch. $1, \S 5,1821$ N.C. Laws 1434 , ch. $962, \$ 5$.

46. Report of Select Joint Committee on the Judiciary, Senate Journal 113, 115 (1819). Cf. The Star (Raleigh), Dec. 11, 1818, p. 3, col. 1 (with the creation of the supreme court the state 'judicial system"will now inspire a confidence and respect which the utmost industry and talent could not before give to it').

47. See Western Carolinian (Salisbury), Feb. 13, 1827, p. 1, col. 1; The Patriot (Greensborough), Feb. 3, 1827, p. 1, col. 4 (complaint of Mr. Morehead from Guilford County that civil and criminal cases took much of the courts' time, to the exclusion of equity cases thereby requiring a transfer to the supreme court with greater cost $)$.

48. Cf. William K. Boyd, History, supra note 29 at ii, 70; Archibald Henderson, North Carolina: The Old North State and the New, 2 vols. (Chicago, 1941) ii, 31.

49. See, e.g., Western Carolinian (Salisbury), Dec. 13, 1825, p. 2, col. 3 (resolution to investigate establishment of separate equity courts to be manned by justices of the supreme court).

50. Tarborough Free Press, Dec. 6, 1833, p. 2, col. 2. (bill would add an additional circuit in the west, abolish the supreme court, and have the circuit judges sit in review of their own judgments, with a salary of $\$ 2000$ ). 
He further anticipated that even if that plan failed there would be another and that it would take but one change in the court to 'make a break thro' the dam-the waters will soon demolish it [the court] entirely'. ${ }^{51}$

Yancey, who represented the wealthy tobacco interests in Caswell County on the border with Virginia, agreed with Gaston's observations. He reported that he had heard much discussion of plans 'to prostrate the present Supreme Court; or what is the same thing, [to] change . . . the Court by placing the present Judges on the Circuit \& directing the Supreme Court to be holden by all the Circuit Judges'. He echoed Gaston's objections to judges reviewing their own decisions and added that having the same judges on circuit as on the supreme court was 'abhorrent to any opinion of a correct and able judicial tribunal of the last resort' ${ }^{52}$ Thus the Whigs found most appealing the very attribute that the democrats found most objectionable in the supreme court-its separation from regular contact with the people.

\section{II}

A.

With the opposing forces arrayed, the supreme court faced considerable uncertainty about its future. Even though the legislature passed no law concerning the supreme court in the session of 1821, in each of the next dozen legislative sessions, all of the state courts remained targets of the general democratic assault on governmental institutions. As the decade of the 1820's waned, the demands for reform intensified, coming closer each year to success. A bill to allow the people to elect the sheriff in each county became law in January 1830, after failing in each of several preceding legislative sessions..$^{53}$ On the heels of that statute came renewed efforts to pass a bill to have the people elect the clerks of the various courts. ${ }^{54}$

51. SHC, Bartlett Yancey Papers, Gaston to Yancey, July 15, 1821.

52. SHC, William Gaston Papers, Yancey to Gaston, Sept. 25, 1821 (text of letter refers to its being in response to Gaston's letter of July 1821). In 1817 Yancey had chaired a legislative committee which unsuccessfully proposed a separate supreme court. Many of the thoughts in this letter are also found in the committee report. See N.C. Coll., Report (n.d.). (The date is suggested in Guion G. Johnson, Ante-Bellum North Carolina, supra note 29 at 626.) See also Raleigh Register (semi-weekly), Feb. 6, 1827 , p. 1 , col. 1 (to require judges to sit on equity courts is the 'overthrow of everything deserving the name of Supreme Court in the State').

53. Act of 1829 , ch. 5, 1837 N.C. Rev. Stat. 564, ch. 109. For an account of the remarkably similar 'democratic impulse' in South Carolina see James W. Ely, Jr., "'That no office whatever be held during life or good behavior:" Judicial Impeachments and the Struggle for Democracy in South Carolina', 30 Vanderbilt Law Review 167-209 (1977).

54. New Bern Spectator, Dec. 8, 1832, p. 3, col. 2. The controversy over the clerks is understandable in light of the fact that along with justices of the peace and sheriffs, the clerks were the most influential county officials. Paul W. Wager, County Government, supra note 37 at 222 . 
The sponsor of the successful bill concerning clerks was Senator Spencer O'Brien, an early leader in the political faction that supported Andrew Jackson. ${ }^{55} \mathrm{O}$ 'Brien explained that the present method of appointing clerks for a term 'during good behaviour' was 'wrong in principle'. Furthermore, he reported that 'it led to the evil in legislation of having batches of Justices commissioned when one party prevailed in a County, to remove or elect one man; and perhaps the next year, the same process would be resorted to for unmaking the same individual, who had been made the year before' ${ }^{56}$ What 'the people' wanted, he explained, was to elect the clerks. Senator William P. Dobson, from the northwestern part of the state, expressed additional democratic sentiment in support of the bill with his complaint that lawyers controlled 'the courts, and when these courts appoint all their officers, they form an autocracy not sufficiently amenable to the people, and we think, dangerous to liberty'. ${ }^{57}$

For at least one supporter of the bill, however, there was reason to pause before enacting it. He doubted that the legislature had the power to remove sitting clerks from office without some fault of the clerks. ${ }^{58}$ An opponent agreed that the bill would remove the sitting clerks: Ninian Edmundson of Haywood County, in the extreme western section of the state, argued that

55. See William S. Hoffman, Andrew Jackson and North Carolina Politics (Chapel Hill, 1958) 28 (vol. 40 of the James Sprunt Studies in History and Political Science).

56. New Bern Spectator, Dec. 8, 1832, p. 3, col. 2. The statement is difficult to relate to statute law. The clerks held office during good behavior under an act of 1806 which empowered the judges to appoint the clerks, who would serve 'during good behaviour'. The act of 1806 , ch. $1, \$ 10,1821$ N.C. Laws $1050,1053-54$, ch. $193, \$ 10$, provided for clerks of the newly created superior courts for each county. The act further provided that the clerks would be 'subject to the same rules, regulations, and penalties as the clerks of the superior courts . . . heretofore established by law'. Ibid. The earlier act, passed in 1777, provided that the clerks should 'hold their offices during their good behaviour therein'. Act of 1777 , ch. $2, \$ 4,1821$ N.C. Laws 281,282 , ch. 115 , \$4. (Appointments under that act proved to be a source of dispute; the legislature amended it in 1794 to require that appointments be made by a majority of the judges. Act of 1794 , ch. 23,1821 N.C. Laws 763 , ch. 423.) The only basis for a turnover of clerks seems to come from an 1822 statute which provided: 'That from and after the passing of this act, that the clerks of the supreme court and all . . clerks of the superior courts . . . to be appointed under the laws of this state, shall be appointed for the term of four years.' Act of 1822, ch. 19, $\$ 1,1827$ N.C. Rev. Laws 72, 72, ch. 1147, §1. The prospective nature of the statute probably explains the lack of any challenge to its constitutionality. Cf. Raleigh Register, Jan. 3, 1823, p. 2, col. 2 (clerks 'could hereafter be appointed for four years where vacancies occur'); The Star (Raleigh), Jan. 3,1823 , p.1, col. 2 (clerks 'are hereafter to be appointed for four years where vacancies occur'). Yet the second section provided that sitting clerks could be removed by the judges of their courts, a manifest change in the tenure provisions of the earlier acts. The rapid turnover described in the text may have been the result of those removal provisions.

57. Greensborough Patriot, Dec. 5, 1832, p. 3, col. 2.

58. New Bern Spectator, Dec. 21, 1832, p. 3, col. 2. The Greensborough Patriot likewise had no doubt that the law effectively 'declare[d] all the offices absolutely vacant'. Greensborough Patriot, Dec. 12, 1832, p. 3, col. 2. 
the people had not 'declared in favor of legislating the present clerks out of their offices. Such however is the bill on your table'. ${ }^{59}$ In spite of those doubts, the bill passed. ${ }^{60}$

It soon became known that most of the incumbent clerks intended to vacate their offices and not challenge the law. But one, Lawson Henderson, the clerk for the superior court of Lincoln County, declined to resign or to stand for election. ${ }^{6}$ Henderson's service as clerk dated from the creation of the superior court in Lincoln County in $1807,{ }^{62}$ when he was appointed to serve 'during good behaviour' ${ }^{63}$ His challenger, John D. Hoke, contended that he was the proper holder of the office, based on his overwhelming election in August 1833. ${ }^{64}$

There is no surviving evidence of the motive for Henderson's decision. ${ }^{65}$ One secondary report, without indication of a source for its knowledge, states that Henderson 'refused to vacate the office on the ground that it was his property for life' ${ }^{66}$ But that explanation is a description more of the subsequent legal argument than of Henderson's motive. It is possible that the decision grew out of a localized political dispute since it was not unheard of for rival political factions to battle over the office of court clerk. ${ }^{67}$ But

59. New Bern Spectator, Dec. 8, 1832, p. 3, col. 2. The South Carolina legislature passed a similar law but amended it to exempt incumbents. James W. Ely, Jr., 'Judicial Impeachments', supra note 53 at 205-06.

60. Act of 1832, ch. 2. See North Carolina Journal (Fayetteville), Dec. 19, 1832, p. 1, col. 5. See also New Bern Spectator, Dec. 21, 1832, p. 3, col. 2.

61. James Graham to William A. Graham, Feb. 7, 1833, Joseph G. de R. Hamilton, ed., The Papers of William Alexander Graham, 2 vols. (Raleigh, N.C., 1957) i, 250, 252.

62. William L. Sherrill, Annals of Lincoln County North Carolina (Charlotte, 1937) 107; Alfred Nixon, 'The History of Lincoln County', North Carolina Booklet ix (1910) 111, 138-39.

63. Henderson may have been one of the few remaining clerks serving during good behavior. The other clerks may have served under the provision of later acts. For a discussion of tenure of clerks see note 56 supra. The surviving records from Lincoln County do not provide evidence of Henderson's service before 1829. Thereafter, however, the records contain the bond that he filed each year from 1829 to 1835 . See State Archives, Register of Official Bonds, Lincoln County. No minute docket for the superior court of Lincoln County exists for the years of Henderson's service before 1816. During the years 1816 to 1825 there are no notations concerning Henderson that would suggest that he was reappointed under any statute. There is, though, a reference to a deputy clerk who 'came into open court \& qualified according to law'. State Archives, Minute Docket, Superior Court of Lincoln County, Fall Term 1833, 163. That entry, and the absence of any similar entry for Henderson, suggests that he continued to serve under his initial qualification in 1807.

64. Hoke received a considerable majority, winning by better than a two-to-one vote over the only other candidate. State Archives, Election Returns for 1833, Lincoln County.

65. Histories of Lincoln County note the dispute between Henderson and Hoke; but no one explains the origin of the dispute. E.g., William L. Sherrill, Annals, supra note 62 at 107; Alfred Nixon, 'History', supra note 62 at $111,138-39$.

66. William L. Sherrill, Annals, supra note 62 at 130.

67. Guion G. Johnson, Ante-Bellum North Carolina, supra note 29 at 32-33. 
other than the fact that both Henderson and Hoke were members of prominent families in Lincoln County, ${ }^{68}$ there is no indication that they represented competing family interests beyond an apparently isolated dispute over real property. ${ }^{69}$

When the parties took their dispute before superior court judge William Norwood, he held that the 1832 act, which divested Henderson and made clerks electable, was unconstitutional. ${ }^{70}$ The case, replete with difficulties for a court already under attack by the sponsors of the challenged statute, then went to the supreme court.

B.

The judges themselves had followed the increasing strength of the democrats with apprehension, recognizing that the statutes creating elective sheriffs and court clerks were but steps toward changes in the judiciary. The judges found the repeated efforts to reduce their salaries particularly objectionable and foreboding. ${ }^{71}$ In December 1828, Chief Justice John Louis Taylor had written to Thomas Ruffin, who was then a judge of the superior court, and explained the practical effects of a reduction in salary. Taylor related that he wanted to continue living in the country, rather than in the city of Raleigh. He thought he could do so, he explained, unless the legislature reduced the salary below $\$ 2000$. 'A reduction of the salary simply to $\$ 2000$ would not change my resolution. A reduction below that sum would unavoidably make an entire change in my life, and no longer leave me master of my possessions. ${ }^{72}$

Ruffin was fully aware of the legislative activity and its implications for he hoped that a long judicial career lay ahead of him. Between 1825 and 1828 he had sat on the superior court, riding circuit with the other judges. But he evidently had his eye on the next vacancy on the state supreme court. ${ }^{73}$ Before a vacancy occurred, however, the presidency of the state

68. See William L. Sherrill, Annals, supra note 62 at I11, 129-30; Alfred Nixon, 'History', supra note 62 at $111,138-39$.

69. See Hoke v. Henderson, 14 N.C. 12 (1831).

70. See State Archives, Minute Docket, Superior Court of Lincoln County, Fall Term $1833,174-75$. There is no reference to any appearance by attorneys for either side. The minute entry of Judge Norwood's disposition contains no reference to precedent, or other authority. There is no copy of a written opinion by Judge Norwood.

71. In 1823, for example, a bill to reduce the salaries passed the House by a vote of 65-37. House Journal, Dec. 30, 1823, 227-28. The Senate rejected the bill by a vote of 30-20. Senate Journal, Dec. 31, 1823, 105. Ten years later, both the Senate and the House rejected bills to reduce the salaries of judges. Senate Journal, Dec. 19, 1833, 65 (vote 38-23); House Journal, Dec. 10, 1833, 175-76 (vote 79-51).

72. Joseph G. de R. Hamilton, ed., Ruffin Papers, supra note 35 at i, 461.

73. Cf. ibid. at 470-71, John M. Dick to Ruffin, Feb. 12, 1829 (refers to conversation with 
bank became available. While trying to decide whether to accept the presidency or to wait for a supreme court seat, Ruffin wrote to a close friend, Peter Browne, setting out various arguments for accepting each office. Ruffin was especially concerned about the effect of another of the recurring proposals to weaken the supreme court-the requirement that judges ride circuit for newly created equity courts. Browne's response recalled Gaston's fears in his letter to Yancey that the first successful attack on the court would open the floodgates for many more. Browne wrote that he was 'fully convinced that the first alterations, either for the better or worse, will be followed by others, until they amount to actual or virtual annihilation'. ${ }^{74}$ Possibly influenced by apprehensions of legislative interference with the courts, Ruffin decided to take the position with the state bank, in spite of the opposition the appointment raised. ${ }^{75}$

When Chief Justice Taylor died less than a year later, Ruffin's friends importuned him to accept the seat on the court if offered ${ }^{76}$ The council of state appointed John D. Toomer to fill the vacancy on an interim basis ${ }^{77}$ but the legislature chose Ruffin to fill the seat when it met six months later. ${ }^{78}$ Ruffin obviously had the support of many throughout the state ${ }^{79}$ one historian has written that in the late 1820 s, Ruffin 'was the most highly esteemed citizen and the most popular man in the State' ${ }^{80}$ But one of Ruffin's correspondents alerted him to his weakness in the eastern part of the state: 'If Mr. Gaston [a native of eastern North Carolina] was a candidate, I find there would be considerable difference of opinion among them, as to which of you ought to be selected . . . but it is now generally

Ruffin in November 1828 when Ruffin expressed his preference for the court seat rather than a post at the state bank); William J. Peele, Lives of Distinguished North Carolinians (Raleigh, 1898) 291 (Ruffin declined appointment to U.S. Senate in 1829 in preference to a legal career).

74. Joseph G. de R. Hamilton, ed., Ruffin Papers, supra note 35 at i, 447, Browne to Ruffin, Aug. 7, 1828.

75. See, e.g., ibid. at 456, 457, Frederick Nash to Ruffin, Nov. 22, 1828; ibid. at 469 , Patrick Henry Winston to Ruffin, Feb. 10, 1829; ibid. at 482, 483, John L. Henderson to Ruffin, Mar. 6, 1829.

76. E.g., ibid. at 467 , John L. Henderson to Ruffin, Jan. 30, 1829.

77. Section 20 of the 1776 state constitution authorized the governor to make interim appointments, with the advice of the council.

78. See Raleigh Register, Nov. 26, 1829, p. 3, col. 1 (Ruffin elected on fourth ballot).

79. See Joseph G. de R. Hamilton, ed., Ruffin Papers, supra note 35 at i, 470-71, John M. Dick to Ruffin, Feb. 12, 1829; ibid. at 471-72, Frederick Nash to Ruffin, Feb. 12, 1829; ibid. at 482-83, John L. Henderson to Ruffin, Mar. 6, 1829; ibid. at 490-91, David F. Caldwell to Ruffin, Mar. 30, 1829; ibid. at 496, Emmanuel Shober to Ruffin, Apr. 24, 1829; ibid., Andrew Joyner to Ruffin, Apr. 25, 1829.

80. Samuel A'Court Ashe, History of North Carolina, 2 vols. (Greensboro, N.C., 1925) ii, 322. 
understood that he positively declines' ${ }^{81}$ Moreover, Ruffin's prestige alone was insufficient to block continued attacks on the court. Indeed, the efforts seemed to intensify after the remaining two original members of court left the bench: Judge John Hall resigned in 1832 and Chief Justice Leorard Henderson died in $1833 .{ }^{82}$

The court's institutional fragility was evident from a laconic remark in the North Carolina Journal at the end of 1832: 'Our Correspondent at Raleigh, informs us that Judge Hall has resigned his office of Judge of the Supreme Court of this State. . . . It is believed that the present Supreme Court system will be abolished. ${ }^{83}$ Support for that belief came from a bill to abolish the supreme court and restore the conference court. ${ }^{84}$

During the same session of the legislature, the correspondent of the New Bern Spectator was equally gloomy in his forecast that the House of Commons would join the Senate in passing a bill to reduce the salaries of the supreme court judges by twenty percent, from $\$ 2500$ to $\$ 2000 .{ }^{85}$ The bill continued the practice of indirect attacks on the court, anticipating that a single victory would trigger a comprehensive assault on the court. Thus, the correspondent predicted that the bill would 'be the means of creating an unexpected vacancy on the bench. It is a pity,' he continued, 'that the bill for abolishing the Court and restoring the old system, did not pass, (it failed only by a tight vote)-for that the present Court will only hold out for a few years a sickly existence, I judge from the indications of the present winter' ${ }^{96}$ Priestly H. Mangum, speaking in the House of Commons, echoed those fears. He reported that he had heard that the purpose of the bill was to effect the destruction of the supreme court. ${ }^{87}$ William Gaston also opposed the bill. He wrote to his daughter about the bill and, in passing, provided what must have been a bit of autobiographical explanation for his own unwillingness to be a candidate for the vacancy on the court. Referring to the bill to reduce the salaries as a 'shameless deed', he explained that such 'contempt of public faith has an inevitable tendency to render men of

81. Joseph G. de R. Hamilton, ed., Ruffin Papers, supra note 35 at i, 496, Andrew Joyner to Ruffin, Apr. 25, 1829.

82. Cf. Archibald Henderson, North Carolina, supra note 48 at ii, 35 (" $[\mathrm{T}]$ he death of Chief Justice Henderson in 1833 removed one of the main props of a court which had never been entirely popular since it was established').

83. North Carolina Journal, Dec. 19, 1832, p. 3, col. 4.

84. See New Bern Spectator, Dec. 21, 1832, p. 3 col. 2 (bill reported in the Senate; motion defeated which would have postponed the bill indefinitely).

85. Cf. Raleigh Register, Jan. 4, 1833, p. 2, col. 5 (bill passed by Senate).

86. New Bern Spectator, Jan. 4, 1833, p. 3, col. 3 (emphasis in original).

87. Raleigh Register, Jan. 18, 1833, p. 2, col. 1. Cf. SHC, William Gaston Papers, Gaston to his daughter Hannah Manly, Dec. 31, 1832 (commenting upon the doubt that the General Assembly would fill the vacancy caused by Hall's resignation and deploring the likely passage of the bill to reduce the judges' salaries). 
sensibility unwilling to place themselves in a state of dependence on such a body' ${ }^{88}$ By a narrow vote (59 to 55), however, the House of Commons defeated the bill, voting to postpone it indefinitely. ${ }^{89}$

Nevertheless, the future of the supreme court was no brighter when Chief Justice Henderson died late in the summer of 1833. The democratic forces were likely to advocate even more strongly the whole range of measures to alter the system now that the court lacked the prestige of a long-serving member ${ }^{90}$ Realization of this prompted one of the state's leading attorneys and a former Federalist, Thomas P. Devereux, to begin immediately a campaign to rally support against the democrats and to persuade Gaston to be a candidate for the supreme court vacancy. 'Nothing', he wrote Gaston, 'can save the Supreme Court unless you will consent to take a seat upon it'. Gaston's willingness to serve on the court was, Devereux urged repeatedly, 'the only thing which can restore confidence to the public mind' ${ }^{91} \mathrm{De}$ vereux spoke primarily for the Whigs, for he added that the universality of sentiment for Gaston arose 'in the circle in which I associate, Governor Swain included'. ${ }^{92}$ David Swain, the first Whig governor of the state, had made almost the same prediction to Gaston immediately after learning of Chief Justice Henderson's death: '[I]f any other name [than yours] is presented the Supreme Court dies with the lamented Ch. J. ${ }^{93}$

Ruffin himself also joined in urging Gaston to serve. Ruffin repeated to Gaston what he had said to Devereux - that he would 'rather serve with [Gaston] than with any man on earth' ${ }^{94}$ At the fore of Ruffin's thoughts, though, were the legislative threats. He alerted Gaston that he would continue in office. He explained to Gaston that he could 'submit to any law', but he could not submit to what he termed 'the unauthorized caprice of the sycophants (not the representatives) of the people'. ${ }^{95}$

88. SHC, William Gaston Papers, Gaston to Hannah Manly, Dec. 31, 1831.

89. Raleigh Register, Jan. 11, 1833, p. 2, col. 6.

90. Along with the late Judge Taylor, Hall and Henderson were the longest serving judges of the nineteenth century. See John L. Cheney, Jr., ed., North Carolina Government, 1585-1979, supra note 38 at $360-61,575-76$.

91. SHC, William Gaston Papers, Devereux to Gaston, Aug. 15, 1833; see also ibid., Devereux to Gaston, Aug. 20, 1833; ibid., Devereux to Gaston, Aug. 21, 1833.

92. Ibid., Devereux to Gaston, Aug. 21, 1833.

93. Ibid., Swain to Gaston, Aug. 15, 1833. Swain repeated his prediction in another letter less than two weeks later. Ibid., Swain to Gaston, Aug. 27, 1833. See also ibid., G.E. Badger and T.P. Devereux to Gaston, Sept. 3, 1833. On Swain see Carolyn A. Wallace, 'David Lowry Swain, The First Whig Governor of North Carolina', in Joseph C. Sitterson, ed., Studies in Southern History (Chapel Hill, 1957) 62-81 (vol. 39 of the James Sprunt Studies in History and Political Science); Carolyn A. Daniel, 'David Lowry Swain, 1801-1835' (unpublished Ph.D. dissertation, University of North Carolina at Chapel Hill, 1955).

94. SHC, William Gaston Papers, Ruffin to Gaston, Aug. 21, 1833.

95. Ibid., Ruffin to Gaston, Aug. 21, 1833 (emphasis in original). Ruffin's profession of 
Gaston already shared Ruffin's apprehensions about the activities of the legislature, as was evident in his earlier letter to his daughter. The concern grew as he faced the prospect of giving up a profitable practice of law for the bench. His considerable indebtedness made him especially anxious atıut the security of the salary ${ }^{96}$ But he, like Ruffin, also objected strongly in principle to any suggestion that the legislature should control the salaries of judges. He explained to Ruffin that 'the possibility that sooner or later these efforts of Demagogues may be successful in actually destroying the independent tenure of the Judicial office' made him reluctant to accept the position. ${ }^{97}$ And to Devereux, he disavowed any interest in whether the salary was $\$ 2500$ or $\$ 2000$. 'But once appointed', he continued,

I should hold myself bound to resist by the most efficient means all attempts on the part of the legislature to alter, diminish or afterwards take away the salary previously attached to the office. ... If the demagogues should succeed in breaking down the stipulated compensation, I should hold myself unquestionably absolved from the obligation to remain in office. ${ }^{98}$

Finally, late in September 1833, Gaston indicated his willingness to be nominated for the supreme court. ${ }^{99}$ But the announcement did not fill the vacancy. There was at least one challenger to Gaston, superior court judge Henry Seawell, who sought advantage from the sectional animosities and the fact that Gaston was a Roman Catholic. ${ }^{100}$ Throughout the western

indifference to the salary may have resulted from his ownership of several profitable plantations. See Hugh T. Lefler, North Carolina History Told by Contemporaries (Chapel Hill, 1934) 257.

96. SHC, William Gaston Papers, Gaston to Robert Donaldson, Aug. 17, 1833 (reports that his debts amounted to $\$ 8,000$ ).

97. Ibid., Gaston to Ruffin, Aug. 25, 1833.

98. Ibid., Gaston to Devereux, Aug. 26, 1833. See also ibid., Gaston to Devereux, Aug. $19,1833$.

99. Ibid., Gaston to Devereux, Sept. 9, 1833. For an account of the campaign to get Gaston to serve see Joseph H. Schauinger, William Gaston, Carolinian (Milwaukee, 1949) 158-59.

100. SHC, William Gaston Papers, David Swain to Gaston, Nov. 8, 1833; ibid., George E. Badger to Gaston, Nov. 14, 1833. Section 32 of the North Carolina Constitution of 1776 prohibited any person from holding state office 'who shall deny the being of God, or the truth of the protestant religion, or the divine authority either of the old or new testament'. For correspondence concerning Gaston's eligibility to hold office see SiHC, William Gaston Papers, Ruffin to Gaston, May 23, 1832; ibid., Gaston to T.P. Devereux, Aug. 18, 1833, (copy reprinted in Joseph G. de R. Hamilton, ed., Graham Papers, supra note 61 at i, 266-68); SHC, William Gaston Papers, T.P. Devereux to Gaston, Nov. 14, 1833. The question of Gaston's religion remained an issue, at least until the constitutional amendments of 1835 , one of which changed the word 'protestant' to 'Christian'. See SHC, William Gaston Papers, Gaston to William A. Graham, Nov. 12, 1834, reprinted in Joseph G. de R. Hamilton, ed., Graham Papers, 
counties Seawell insinuated that Gaston was the choice of the eastern establishment.

In spite of those efforts, the General Assembly elected Gaston shortly after it began its session in November 1833. ${ }^{101}$ In the same month the General Assembly defeated both a bill to abolish the supreme court and a bill to reduce the judges' salaries. ${ }^{102}$ The Raleigh correspondent for the New Bern Spectator, the newspaper from Gaston's home town, explicitly linked Gaston's election with the defeat of both bills. ${ }^{103}$ The correspondent of the Tarborough Free Press concurred, writing of the failure of a bill to reduce salaries: 'The Court is decidedly more popular with the Legislature than it ever was, and I presume this is owing in great degree to the high character, for talents and integrity, of the gentleman last elected to its Bench [Gaston]'. ${ }^{104}$ Similarly, the correspondent of the Fayetteville Observer wrote that the accession of Mr. Gaston to the Bench has made the Court stronger, if possible, than ever before. No open attack can now avail [illegible] against it'. ${ }^{105}$

supra note 61 at i, 326-30 (for Graham's response see ibid. at 365-66); SHC, William Gaston Papers, Joseph Hopkinson to Gaston, Dec. 28, 1834 (reporting rumor that Gaston was to be removed from office); ibid., Gaston to Joseph Hopkinson, Jan. 13, 1835 (photocopy of original in the Genealogical Society of Pennsylvania); ibid., Gaston to Cornelius C. Baldwin, Dec. 29, 1835 (explaining Gaston's views on the Catholic issue and denying rumor that he had gone to Baltimore in 1833 to seek permission from the Bishop there to join the court). For a general discussion of Catholics in North Carolina at the time see Stephen C. Worsley, 'Catholicism in Antebellum North Carolina', North Carolina Historical Review Ix (1983) 399-430.

101. New Bern Spectator, Dec. 6, 1833, p. 3, col. 2. Raleigh Register, Dec. 3, 1833, p. 3, col. 2.

102. Senate Journal, Dec. $19,1833,65$ (38-23 vote to indefinitely postpone bill to regulate salaries); House Journal, Dec. 7, 1833, 172 (102-23 vote to indefinitely postpone bill to 'alter and amend' judicial system); ibid., Dec. 10, 1833, 175-76 (79-51 vote to postpone indefinitely bill to reduce salaries); see New Bern Spectator, Dec. 6, 1833, p. 3, col. 2 (defeat predicted); ibid., Dec. 20, 1833, p. 3, col. 2 (reports defeat of bills to destroy the court); Raleigh Register, Dec. 10, 1833, p. 3, cols. 2, 5; ibid., Dec. 24, 1833, p. 3, col. 1. Earlier in the session the House of Commons had "promptly rejected without debate' a motion directing its judiciary committee to investigate the expedience of repealing the act that established the supreme court. New Bern Spectator, Nov. 29, 1833, p. 3, col. 2; ibid., Dec. 6, 1833, p. 3, col. 2.

103. New Bern Spectator, Dec. 20, 1833, p. 3, col. 2.

104. Tarborough Free Press, Dec. 13, 1833, p. 2, col. 3. The correspondent for that newspaper had been decidedly optimistic about the fate of the court in the face of the bills that session. See ibid., Nov. 29, 1833, p. 2, col. 4 (Commons bill to reduce salaries 'cannot pass').

105. Fayetteville Observer, Dec. 17, 1833, p. 3, col. 1. Cf. Joseph G. de R. Hamilton, ed., Graham Papers, supra note 61 at i, 271, 273, Hugh Waddell to William A. Graham, Dec. 15, 1833 (comment that the legislature had elected Gaston and Swain [as governor] and saved the supreme court; Waddell was a prominent Whig). The impact of 
The appointment of Gaston stilled for the moment the efforts to destroy the court. But no one could know how long the calm would last, especially in light of the growing support for a constitutional convention. Thus, when the appeal in Hoke arrived, shortly after Gaston took his seat, the court recognized the opportunity to speak publicly on an issue that had privately troubled Ruffin and Gaston for fifteen years. Their apprehensions about efforts to make state government more 'responsive' to the people had driven Ruffin to the brink of resignation and had made Gaston loath to accept the nomination. The opportunity was especially apt because the clerks and the judges of the supreme court were in precariously similar positions in that both served in offices created by statute which declared their tenure tis be 'during good behaviour'. ${ }^{106}$ Neither had unquestioned constitutional protection in office.

The absence of constitutional protection would later prove decisive for every other court that considered questions similar to those presented in Hoke. These other decisions established the rule that a legislature could not alter that which the constitution provided, from tenure to salary. But a legislature had unrestrained power to alter any office not so protected. As Chief Justice Shaw of Massachusetts wrote: 'Where an office is created by law, and one not contemplated, nor its tenure declared by the constitution, but created by law solely for the public benefit, it may be regulated, limited, enlarged or terminated by law, as public exigency may require' ${ }^{107}$ In light of the general language in the North Carolina constitution of 1776, there was at least a potential argument that the constitution provided no restraint on the legislature in dealing with the offices it had created, clerks as well as supreme court judges. To defend against that potential, Ruffin, writing for the court, set about establishing a large sphere within which the legislature could not interfere with the judiciary.

Ruffin used three steps to reach his conclusion that the legislature had acted unconstitutionally. ${ }^{108}$ First, he explained that the statute ousted the

Gaston is further evidenced by the fact that upon his death in 1846 there was renewed discussion of eliminating the supreme court. SHC, Ruffin-Roulhac-Hamilton Papers, Catherine Roulhac [Ruffin's daughter] to Joseph Roulhac, Dec. 5, 1846.

106. See text at notes $32 \& 56$ supra.

107. Taft v. Adams, 3 Gray (Mass.) 126, 130 (1855). Judge Thomas Cooley of Michigan expressed similar views in City of Wyandotte v. Drennan, 46 Mich. 478, 480-31 (1881).

108. Unfortunately, no records of the case or of the briefs of counsel appear to have survived. The records of the Supreme Court of North Carolina are now housed at the State Archives in Raleigh; but there is no file for the decision. There is a copy of Judge Norwood's minute decision but it is misfiled, with the record of a different case between the same parties, Hoke v. Henderson, 14 N.C. 12 (1831), State Archives, Supreme Court of North Carolina, Records of Original Cases, file 2282. The other case 
sitting clerks. Second, he wrote an essay on the nature of separation of powers and concluded that the legislature could not perform a judicial act. Third, he held that a clerk had a property interest in his office-a right that could be restricted only in accord with the 'law of the land', ${ }^{109}$ which Ruffin interpreted as requiring some form of judicial proceeding.

Only the third step in the analysis is remarkable; that holding is contrary to the rule in every other American jurisdiction. ${ }^{110}$ But Ruffin's opinion rather neatly used the first two steps to predispose the discussion toward the outcome on the third as well as to bow repeatedly toward the legislature. By so doing he achieved the desired political effect of appeasing the legislature while at the same time warning it not to tamper with the judiciary.

The first question posed a problem only because the statute was so poorly worded that it failed to declare that sitting clerks were no longer to hold office. Ruffin might have taken advantage of the poor wording to interpret the act as being prospective only, thereby avoiding the constitutional issue altogether. But he chose not to do so, apparently aware of the common understanding during the legislative debate that the bill would apply to incumbent clerks. "II Ruffin carefully parsed the statute to show that incumbent clerks must run for election if they hoped to remain in office. ${ }^{112}$ Ruffin did more, however, than list the sections that made the conclusion seem irresistible. Like the paradigmatic example of judicial politics, Marbury $v$. Madison, ${ }^{113}$ Ruffin repeatedly went out of his way to disclaim interest in doing anything other than merely following the legislative will. For example, he wrote that the policy and consequences of a statute were 'political considerations, fit to be weighed by and to influence the legislators; but if disregarded by them, their responsibility is to their constituents,

concerns only a land dispute, which had begun some years earlier. I have not been able to locate the record in any other place. I have looked in the papers of Judges Ruffin and Gaston and in the papers of the attorneys involved, Badger, Devereux, and Iredell.

109. This is the point for which the case is know, particularly through the writing of Professor Corwin. See Edward S. Corwin, Liberty Against Government (Baton Rouge, 1948) 72; Edward S. Corwin, "The Doctrine of Due Process of Law Before the Civil War', 24 Harvard Law Review 366, 383-84 (1911). See also Harold M. Hyman \& William C. Wiecek, Equal Justice Under Law: Constitutional Developments 1835 1875 (New York, 1982) 23. As this article argues, however, the decision is far more significant as a political fact than for the unexceptional resort to the concept 'law of the land'.

110. A near contemporary decision noted that Hoke 'stands out in strong contrast . . . to every published decision and opinion on the subject which we have seen'. Conner $v$. Mayor of New York, 2 Sandf. 355, 373 (N.Y. Super. Ct. 1849), aff'd, I Seld. 285 (N.Y. 1851). Later comments were no less definite. See Annotation, American Law Reports (Rochester, 1919) iv, 205, 205; Annotation, American Decisions (San Francisco, 1886) xxv, 677, 701.

111. See text at notes 58 \& 59 supra; Greensborough Patriot, Dec. 12, 1832, p. 3, col. 2.

112. 15 N.C. at $4-6$.

113. 5 U.S. (1 Cranch) 137 (1803). 
not to the courts of justice'. 114 'To a Court', he continued, 'the impolicy, the injustice, the unreasonableness, the severity, the cruelty of a statute by themselves merely, are and ought to be urged in vain'. ${ }^{115}$

Having written his obsequious comments, Ruffin then turned to the second issue: whether the legislature had the power to enact the statute. Quite obviously resolution of that issue depended upon the nature of the statute and upon what the statute did. Ruffin began his discussion by cleverly describing the statute in a way that prejudiced all subsequent discussion. According to Ruffin, the statute 'transfers the office of clerk from one of these parties to the other, without any default of the former, or any judicial sentence of removal'. ${ }^{16} \mathrm{He}$ might have generally characterized the statute as changing the tenure of holding office, leaving to the electorate the task of naming a new clerk. Or he might have responded, as did every other contemporaneous court, by recognizing the democratic impetus of the American revolution and concluding that the people, through their legislators, had the right to alter the terms of public officeholders. ${ }^{117} \mathrm{He}$ chose neither of those options. Instead, his phraseology made the statute into a determination by the legislature of a particular dispute between Hoke and Henderson. What was a statute removing all clerks from office indiscriminately thus became a judicial decision operating between two parties. Ruffin's characterization would prove crucial later in the opinion. But first he turned to an essay on the nature of state government.

Ruffin seemed especially anxious to explain that the court posed no threat to the democratic interests in the legislature. 'Courts', he wrote, 'must enforce [legislative] enactments; for they are laws to them by the mere force of the legislative will'. ${ }^{118} \mathrm{He}$ acknowledged that in rare circumstances the court had an obligation to announce that the legislature had exceeded its powers. ${ }^{119}$ But on those occasions, the legislature was sure to 'rejoice in the rescue of the Constitution from their own incautious and involuntary infraction of it' ${ }^{120}$ There was no reason, according to Ruffin, for the legislature to fear the judiciary, for it had no opportunity to compel acceptance of its own views of policy. Rather, the task of a judge was no more than to implement the very democratic principles embraced by the legislators; it was 'the humbler and easier one of instituting a naked comparison between what the representatives of the people have done [in the legislature], with what the people themselves have said [in the constitution]

114. 15 N.C. at 6.

115. Ibid.

116. Ibid. at 7 .

117. For examples see cases cited in notes $139,144, \& 165$ infra.

118. 15 N.C. at 7.

119. Ibid. at 8-9.

120. Ibid. at 10. 
they might do, or should not do'. ${ }^{121}$ To insure that no one missed his message, Ruffin repeated the self-deprecation by asserting that the task of the judge was comparatively humble'. So humble was the judicial function that it did 'not call for those high attainments required for wise legislation'. ${ }^{122}$

Having sought to allay legislative fears, Ruffin returned to the less palatable portions of the opinion. His language, though, was Marshallian in stating propositions of such grandeur and general acceptance with which no one could disagree. He began with the premise that the 'great object of society [was] to enable men to appropriate among themselves the things which, in their natural state were common'. ${ }^{123}$ From that premise he deduced the whiggish conclusion that the best government was one which protected private property 'even from the government itself'. ${ }^{124}$ Ruffin's language here revealed a sympathy with that of the established interests in the state. Those interests argued that the existing apportionment of the legislature was fair because it reflected property values. Legislative spokesmen could oppose any call for reform by arguing for continued security for property: 'What is the object of all good government? The protection of persons and property; but more especially of property, since that is more apt to be invaded. ${ }^{125}$ Ruffin's only support for his deduction came from two admonitory provisions in the declaration of rights from the North Carolina Constitution of 1776. The first stated that no freeman ought to be ... deprived of his life, liberty, or property, but by the law of the land'. ${ }^{26}$ The second provided 'that the legislative, executive and supreme judicial powers of government ought to be forever separate, and distinct from each other'. ${ }^{127}$

For Ruffin the two principles blended into a single declaration that the legislature could constitutionally do nothing judicial. In that light, his efforts to portray the statute as a judicial act became especially important. Realizing that, Ruffin repeated his definition that anything which took a right from one person and gave it to another was a judicial act. ${ }^{128}$ That the statute did not

121. Ibid. at 8 .

122. Ibid.

123. Ibid. at 11 .

124. Ibid. at 12 .

125. N.C. Coll., Report and Counter Report of the Joint Select Committee on the Subject of Convention 11 (Legislative Document No. 10, 1832, Raleigh) (minority report).

126. North Carolina Constitution of 1776 , Declaration of Rights $\$ 10$, quoted in 15 N.C. at 12. The declaration of rights is part of the constitution even though it precedes the text of that document. North Carolina Constitution of 1776, §44.

127. North Carolina Constitution of 1776 , Declaration of Rights $\$ 4$, quoted in 15 N.C. at 12. For a discussion of the most recent decisions on this point see John V. Orth, "'.Forever Separate and Distinct": Separation of Powers in North Carolina', 62 North Carolina Law Review 1-28 (1984).

128. 15 N.C. at 13. 
name Hoke and Henderson was not decisive, because the effect was to 'compel[] the Courts to deprive the officers [of their offices] without further inquiry before a jury, into the fact or legal sufficiency of any cause of forfeiture or removal' ${ }^{129}$ Furthermore, it did not matter that the statute was not purely judicial, it was enough that 'it partakes of that nature'. ${ }^{130}$

As Professor John Orth has recently noted, such an absolute demarcation of the legislative function ran contrary to the 1776 constitution itself (which assigned certain judicial functions to the legislature) and to the developing spirit of the times (which granted large measures of power to the legislature) ${ }^{131}$ Moreover, Ruffin ignored the actual practice of government in North Carolina. Even a cursory examination would have revealed considerable blurring of the lines between the branches of state government. There were innumerable private laws passed in each legislative session which determined rights between parties by, for example, granting divorces, legitimizing people, and restoring credit. ${ }^{132}$

Ruffin also omitted from his argument the important statutes which had defined the nature of the office of clerk of court. ${ }^{133}$ Nine years after decreeing that clerks should hold office 'during good behaviour', the legislature proclaimed that county clerks who issued writs before receiving the appropriate tax 'shall be deemed guilty of misbehavior in office'. ${ }^{134}$ Fourteen years later the legislature enacted the following statute, which provided its own rationale:

Wheareas doubts are entertained whether the courts of pleas and quarter sessions [the county court] within this state have the power to remove their clerks from office for neglect or misbehaviour:

$B e$ it therefore enacted, \&c. That the said courts of pleas and quarter sessions shall have full power and authority, on their respective clerks being convicted or found guilty, in the courts aforesaid, on a bill of indictment for neglect of duty or misdemeanor in office, to remove such clerk, and proceed to the election of another, provided a majority of the justices of the county are present at the election of such clerk . . . ${ }^{135}$

129. Ibid.

130. Ibid. at 15 .

131. John V. Orth, 'Separation of Powers', supra note 127 at 5-6 and n.28.

132. One need only look at the session laws for any year in the early nineteenth century to find examples. The constitutional amendments of 1835 sharply restricted the legislature's power to enact private laws.

133. The clerks of the county courts held office 'during good behaviour' by virtue of the same 1777 statute which established the tenure of the superior court clerks. Act of 1777 , ch. $2, \S 60,1821$ N.C. Laws 281,306 , ch. $115, \$ 60$.

134. Act of 1786 , ch. $14, \S 12,1821$ N.C. Laws 544,548 , ch. $253, \S 11$ [sic] (the 1821 compilation omits section 9 of the original act).

135. Act of 1800 , ch. 23,1821 N.C. Laws 928 , ch. 563. 
In 1822 the legislature amended the law so that a majority of the judges could remove clerks, apparently without a trial or any other proceeding. ${ }^{136}$

However one might ultimately untangle the statutes, it seems clear that by Ruffin's definition the legislature had performed several judicial acts. First it had declared what should constitute 'misbehaviour in office'; and foresaw no need for a trial to determine guilt since the clerk was to be 'deemed guilty'. Later the legislature retrospectively declared what the law was with respect to the removal of clerks.

Nevertheless, Ruffin persisted in his efforts to corral the legislature. He added the conclusion that the clerks bill violated the 'law of the land' provision because it permitted property to be taken without appropriate procedures. ${ }^{137}$ That this point is but a restatement of his first conclusion is evident from his explanation that the legislature had deprived a 'citizen of his property, without trial before a judicial tribunal, and a decision upon the matter of right, as determined by the laws under which it vested, according to the course, mode and usage of the common law as derived from our forefathers'. ${ }^{138}$

Continuing to write as though the American revolution had made no change in the nature of government, ${ }^{139}$ Ruffin then turned to the key question in the inquiry, the answer to which he had assumed from the start: whether an incumbent had a property right in the office of clerk of the superior court. Ruffin contented himself with the assertion that 'property' was whatever a person could possess and enjoy by right. An office was therefore a property right. He buttressed his conclusion by noting that 'commentators on the law' included an office among 'incorporeal hereditaments'. And, in the crucial part of the opinion, he approved the definition of an office as 'the right to exercise a public or private employment, and to take the fees and emoluments thereunto belonging'. ${ }^{140}$

To support this crucial point Ruffin cited only Blackstone's Commentaries. ${ }^{141} \mathrm{He}$ ignored at least two well known, contemporaneous trea-

136. See note 56 supra.

137. 15 N.C. at 15-16. Ruffin did not, however, refer to section 14 of the declaration of rights which provided: 'That in all controversies at law respecting property, the ancient mode of trial by jury is one of the best securities of the rights of the people, and ought to remain sacred and inviolable.' North Carolina Constitution of 1776, Declaration of Rights §14.

138. 15 N.C. at 16.

139. Cf. Conner v. Mayor of New York, 2 Sand. 355, 374 (N.Y. Super. Ct. 1849) ('It appears to us, with much respect for the learned tribunal which [decided Hoke], that it was unduly influenced by the common law rule derived from prescriptive offices, and operating in a government whose genius and spirit are perhaps in no respect more unlike ours than in this very subject, the source and nature of the rights and interest acquired by public officers'.), aff'd, 1 Seld. 285 (1851).

140. 15 N.C. at 17.

141. William Blackstone, Commentaries on the Laws of England ii, 36. 
tises. One was St. George Tucker's 1803 annotation of the very point in the Commentaries. To demonstrate the anachronism of Blackstone, the annotation referred to the Virginia bill of rights which provided: 'No man can have an estate of inheritance in any public office in Virginia." ${ }^{142}$ The other treatise was Chancellor James Kent's Commentaries, the first (1828) and second (1832) editions of which provided:

In the United States, no public office can properly be termed an hereditament, or a thing capable of being inherited. The constitution, or the law of the state, provides for the extent of the duration of the office, which is never more permanent than during good behaviour. . . It would not be consistent with our manners and usages, to grant a private trust or employment to one, and his heirs, in fee; though I do not know of any positive objection to such a contract in point of law. ${ }^{143}$

The extent to which Ruffin's opinion was inconsistent with the democratic spirit of the times is further evidenced by decisions of two other state courts in the year following Hoke. Both bluntly rejected Ruffin's conclusion. In Georgia the court wrote: 'That a public office is the property of him to whom the execution of its duties is entrusted, is repugnant to the institutions of our country and is at issue with that universal understanding of the community which is the result of those institutions. ${ }^{144}$ The New York Supreme Court had a similar opinion:

It is an unsound and even absurd proposition, that political power, conferred by the legislature, can become a vested right as against the government in any individual or body of men. It is repugnant to the genius of our institutions, and the spirit and mearing of the constitution; for by that fundamental law, all political rights not there defined and taken out of the exercise of the legislative discretion, were intended to be left subject to its regulation. ${ }^{145}$

Ruffin apparently recognized the difficulty with his position for he then made a series of concessions in which he acknowledged that a 'property' right in a public office was different from a 'property' right in a parcel of land. For instance, he admitted that the right to a public office was not absolute but existed only 'in safety to the general interest' ${ }^{146}$ The right

142. St. George Tucker, Blackstone's Commentaries, 4 vols., (Philadelphia, 1803) ii, $36 \mathrm{n}$. Ruffin did not mention the North Carolina declaration of rights which provided ' $[t]$ hat no hereditary emoluments, privileges or honours, ought to be granted or conferred in this state'. North Carolina Constitution of 1776, Declaration of Rights \$22.

143. James Kent, Commentaries on American law, 4 vols. (1st ed. New York, 182.8) iii, 362; ibid. (2d ed. New York, 1832) iii, 454.

144. State ex rel. Mayor of Savannah v. Dews, R.M. Charlt. 397, 400 (Ga. 1835). For a long discussion of the differences between England and the United States on this; point see ibid. at $400-05$.

145. People v. Morris, 12 Wend. 325, 331-32 (N.Y. Super. Ct. 1835).

146. 15 N.C. at 18. 
could not be alienated; but he thought that not critical to the characterization since the legislature had the authority to require certain formalities in the case of wills or transactions with infants or married women. ${ }^{147}$ Neither could the holder of a public office substitute another or ignore the office, as could be done with what Ruffin termed the 'ordinary right of property'. 148 With those concessions, it is difficult to know what was left of the 'property' right. About all that could be done was to assert a claim to salary or fees, which Ruffin steadfastly concluded made it

the subject of property, as every other thing corporeal or incorporeal, from which men can earn a livelihood and make gain. The office is created for public purposes; but it is conferred on a particular man and accepted by him as a source of individual emolument. To the extent of the emolument it is private property, as much as the land which he tills, or the horse he rides, or the debt which is owing to him. ${ }^{149}$

Ruffin's characterization more closely resembled a 'contract' right than a property right. Had he used the term 'contract' he would have followed a usage common in North Carolina at the time. During debates on proposals to reduce the judges' salaries, Gaston and other legislators had regularly referred to a contract between the state and the judges which could not be broken by either side. ${ }^{150}$ Ruffin's adherence to the 'property' characterization is understandable in light of the fact that there was no protection for contract rights in the state constitution. The contracts clause of the federal constitution ${ }^{151}$ likewise offered no protection. ${ }^{152}$ So Ruffin was forced to find a property right if he was to protect the clerks.

To this point in his opinion Ruffin had jealously guarded the judicial power. He had used flattery and disclaimer to emphasize the principle that the legislature could constitutionally do nothing that even partook of the judicial. There remained, however, unanswered arguments. Ruffin turned to them with an eye on the case and his memory acutely aware of legislative attempts to strike at the courts. The first of these remaining arguments brought Ruffin back to the fundamental point he had glossed over earlier: whether post-revolutionary doctrine precluded holding that there was a property right in a public office. Ruffin provided a negative answer to the question without doing anything other than repeating his conclusion that an

147. Ibid.

148. Ibid.

149. Ibid. at 18-19.

150. See Raleigh Register, Dec. 1, 1819, p. 1, col. 4; Senate Journal, 1819, 116; Raleigh Register, Nov. 26, 1829, p. 3, col. 2.

151. United States Constitution, art. 1, $\$ 10$.

152. See Dartmouth College v. Woodward, 17 U.S. (4 Wheat.) 518, 627-29 (1819). Some years later the Supreme Court held that no contract existed between a state and its officers. Butler v. Pennsylvania, 51 U.S. (10 How.) 402 (1851). 
office was property. In doing so, however, he repeatedly took advantage of opportunities to illustrate his point with advice about what the legislature could not do to the judiciary itself. The advice was purely dicta. Ruffin had already supported his conclusion that the right to an office was a property right. The only explanation for the dicta lies in realizing that Ruffin was using his opinion to respond to legislative attacks on the court. Ruffin conceded that unless there was a prohibition in the constitution, the legislature had the power to create and to abolish offices. ${ }^{153} \mathrm{He}$ wrote that a person 'takes the office with the tacit understanding, that the existence of the office depends on the public necessity for it; and that the Legislature is to judge of that' ${ }^{154} \mathrm{He}$ refused, however, to concede that such legislative control over an office meant that the office was not property. He offered no new rationale, only another refrain of the assertion that the office was property. ${ }^{155}$

He also rejected the argument that the power to abolish an office meant that the legislature had the power to discharge the incumbents. '[W]hile: the office remains', he wrote, 'it is not possible that the public interest can be concerned in the question, who performs the services incident to it. The sole concern of the community is, that they should be performed, and well performed, by somebody. ${ }^{156}$ Those sentences belied his earlier disclainers of interest in policy considerations. He also again ignored the democratic spirit which would have favored the argument that the concern of the community also extended to a desire that important public officials be selected by the people rather than appointed by individuals (the judges) not responsive to the electorate. Then Ruffin turned to what was his main point, that an officeholder had a right to the income from the office. 'It is true that a clerk, like all other officers, is a public servant; but he has also a private interest. ${ }^{157}$ That interest, Ruffin explained, was in the emoluments of the office, which could not be transferred without taking value from one person and giving it to another.

As Ruffin offered more explanation he digressed onto the type of tenure afforded a clerk. He thought it for the benefit of the public that some oftices be appointed during good behavior. His reasoning was in keeping with the generally whiggish tone of the opinion: '[The services] may be expected to be best done by those, whose knowledge of them, from time and experience, is most extensive and exact. ${ }^{158}$ That he had in mind more than the

153. 15 N.C. at 20.

154. Ibid.

155. Ibid.

156. Ibid. at 21. Contra, e.g., People ex rel. McMinn v. Haskell, 5 Cal. 357, 359 (1855); Attorney General v. Jochim, 99 Mich. 358, 368 (1894)); People ex rel. Robertson v. Van Gaskin, 5 Mont. 352, 363 (1885)); Foster v. Jones, 29 Va. 642, 644 (18834).

157. 15 N.C. at 21.

158. Ibid. at 23 . 
office of clerk is evident from the example he used-the constitutional provision requiring that judges be appointed during good behavior. And he offered the gratuitous observation that the tenure of judges was for the benefit of the public, so 'that he who is to decide controversies between the powerful and the poor, and especially between the government and an individual, should be independent, in the tenure of his office, of all control and influence, which might impair his impartiality'. ${ }^{159}$ Warming to the topic which had, after all, concerned him keenly for almost a decade, he suggested that without such security, the judiciary would be subject to a variety of pressures, including 'influence . . . produced by the threats of the government to visit nonconformity to their will, by depriving him of office, or rendering it no longer a means of livelihood'. 160

From that digression Ruffin returned to admit that clerks did not have the protection of tenure stated in the constitution. But, he asserted, that did not matter, for once the legislature granted tenure during good behavior it could change it only prospectively. He offered no citation or explanation for his conclusion other than the circular one that there was a property interest in the office. Ruffin thereby effectively eliminated any distinction between constitution and legislation since both served to bind the actions of future legislatures.

Other arguments included the position that there could be no property interest since the legislature had complete power to alter the salary for the office. Ruffin's response would come as no surprise to anyone familiar with his private correspondence: so long as the office was necessary the legislature would not be presumed to abolish it or eliminate its salary merely for the purpose of replacing or starving the officeholders. 'If such a law were to pass, it would itself be unconstitutional-that being the object." ${ }^{161}$ Then, having issued the direct advisory opinion, he retreated, stating that no court had power to inquire into motive. ${ }^{162}$ But the memories were too sharp for him to resist one more attempt at instruction: for the legislature to try to abolish an office indirectly (by eliminating the salary) when it could not do so directly would be 'a gross and wicked infraction of the Constitution' ${ }^{163}$

To be absolutely certain that his point was understood, he provided another example, with this initial disclaimer: "Not to allude to the causes which have been recently the themes of the bitterest political controversies.' 164 'Suppose', he wrote, the legislature were to refuse to elect the judges

159. Ibid.

160. Ibid.

161. Ibid. at 26.

162. Ibid. at 26-27.

163. Ibid. at 27.

164. Ibid. 
or to give them salaries; or, after assigning them salaries in the statute, to refuse to lay taxes, or to collect a revenue to pay them. All these would be plain breaches of constitutional duty; and yet a court could give no remedy, but it must be left to the action of the citizens at large to change unfaithful for more faithful representatives. ${ }^{165}$

Not since John Marshall told James Madison and Thomas Jefferson that withholding a commission was 'not warranted by law [and] violative of a vested right' ${ }^{166}$ had the least dangerous branch penned such pointed chastisement.

The final point that Ruffin attempted to rebut was the suggestion that there could be no property interest since the rights were not mutual; the state might have the obligation to continue the clerk in office but the clerk might freely resign. Ruffin thought otherwise, again resorting to his implicit understanding that a contract right was at issue. Resignation would be ineffective until accepted; without acceptance the clerk remained obliggated to perform. ${ }^{167}$ Again, Ruffin had no precedent for support, only assertion and example. His examples referred not to a general point but to statutes that explicitly provided for an obligation to serve. He seemed not to appreciate that those statutes might be exceptions to a general freedom to resign. Nevertheless, he took the opportunity to offer further instructions about the nature of the officeholder's obligation, obviously influenced by the recent bills to reduce judicial salaries. 'If indeed the public change the emoluments of office, it is another question, whether that be not an implied permission for the officer to retire at his election. . . 168

Ruffin ended the opinion with another disclaimer that the decision was based on other than a dispassionate consideration of all the issues and 'without a desire to swerve to either side from the direct line of the law and the Constitution' ${ }^{169}$ But the court was unanimous in its decision that the law was unconstitutional.

\section{IV}

In striking down one of the democrats' favorite pieces of legislation the court could well have expected a retaliatory rejoinder. But there was no outburst. In fact, Hoke provoked nothing other than perfunctory reports in a few newspapers. The silence in North Carolina is markedly different from

165. Ibid.

166. 5 U.S. (1 Cranch) 162.

167. 15 N.C. at $28-29$.

168. Ibid. at 29. Ruffin's comment is very similar to Gaston's quoted in text at note 98 supra.

169. 15 N.C. at $30-31$. 
more extreme reactions to similar judicial decisions in other states: the abolition of the supreme court in South Carolina and the censuring of the judges in Georgia. There are multiple explanations for the differences. Politics in antebellum North Carolina never became as divisive as in other states, South Carolina in particular. The split between east and west in North Carolina, though sharp, was never so bitter as the feelings about nullification in South Carolina. Moreover, the effect of Hoke was muted by the fact that most clerks had resigned immediately after the statute was passed, making the decision largely meaningless except as an instruction to the legislature. But the court had struck at the democratic notion of an unbounded legislature and the democrats had not reacted. The absence of a reaction suggests that personalities played as important a role as did political philosophies. Ruffin and Gaston together appealed to the major political interests in the state. Ruffin was from the central part of the state. He had flirted with democratic politics; but he wrote a decidedly whiggish opinion in Hoke. What little dislike there was of him arose in the east, and that dislike was mollified by the appointment of Gaston, a native of the east-coast town of New Bern. But Gaston too transcended the sectional lines. He had long been a supporter of internal improvement and constitutional changes favored by the west. Indeed, Gaston was a leader in the convention of 1835 on behalf of democratic reform. With those two men on the court all but the most radical democrats would be assured of an even-handed court, even when it struck down an important aspect of their political agenda. 
